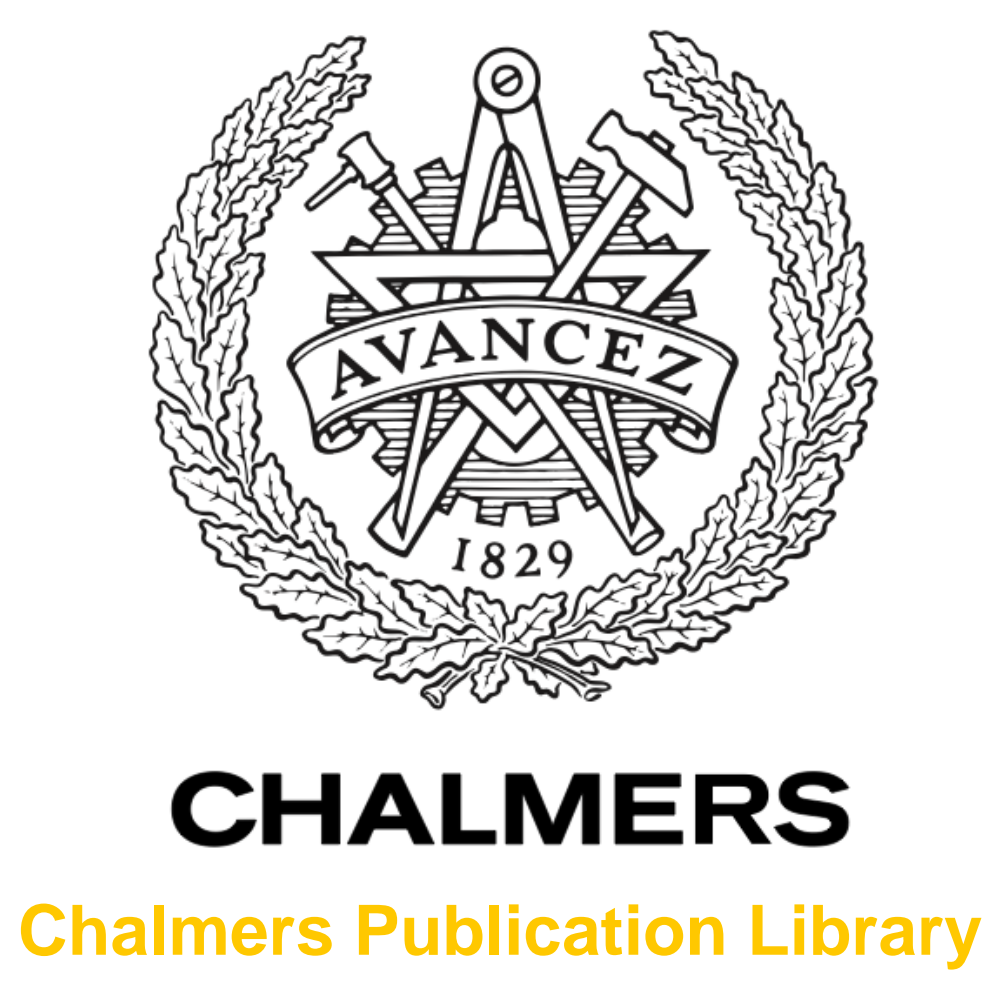

\title{
Methods for reducing the emission of nitrous oxide from circulating fluidized bed combustion
}

This document has been downloaded from Chalmers Publication Library (CPL). It is the author's version of a work that was accepted for publication in:

\section{Energy Conversion and Management}

Citation for the published paper:

Lyngfelt, A. ; Åmand, L. ; Gustavsson, L. et al. (1996) "Methods for reducing the emission of nitrous oxide from circulating fluidized bed combustion". Energy Conversion and

Management, vol. 37 pp. 1297-1302.

Downloaded from: http://publications.lib.chalmers.se/publication/134266

Notice: Changes introduced as a result of publishing processes such as copy-editing and formatting may not be reflected in this document. For a definitive version of this work, please refer to the published source. Please note that access to the published version might require a subscription. 


\title{
METHODS FOR REDUCING THE EMISSION OF NITROUS OXIDE FROM FLUIDIZED BED COMBUSTION
}

\author{
ANDERS LYNGFELT, LARS-ERIK ÅMAND, LENNART GUSTAVSSON \\ and BO LECKNER
}

\author{
Department of Energy Conversion, Chalmers University of Technology, \\ 41296 Göteborg, Sweden, Fax: +46 317723592
}

\begin{abstract}
Two methods for the reduction of nitrous oxide emissions, afterburning and reversed air staging, are investigated in a $12 \mathrm{MW}$ circulating fluidized bed boiler. With afterburning the $\mathrm{N}_{2} \mathrm{O}$ emission can be reduced by $90 \%$ or more, using an amount of secondary fuel corresponding to $10 \%$ of the total energy input. With reversed air staging it is possible to reduce the emission of $\mathrm{N}_{2} \mathrm{O}$ to one fourth ( $25 \mathrm{ppm}$ ), without significantly affecting the other emissions. With reversed air staging no secondary air is used in the combustor and an air-ratio of about unity is maintained throughout the combustion chamber. Air for final combustion is added in the cyclone outlet.
\end{abstract}

\section{INTRODUCTION}

Fluidized bed combustion technology has received a rapidly growing interest, and a large number of commercial boilers of this type have been put into operation during the last 20 years. Important reasons for this development are low emissions of nitric and sulphur oxides $\left(\mathrm{NO}\right.$ and $\left.\mathrm{SO}_{2}\right)$ and fuel flexibility. The low emission of nitric oxide is a consequence of low temperature and of reduction processes during combustion. The low sulphur dioxide emission is a result of limestone addition to the combustion chamber which then acts as a reactor for sulphur capture. Thus, low emissions of nitric and sulphur oxides are realized without equipment for flue gas cleaning downstream of the combustion chamber.

For more than five years, however, it has been known that fluidized bed boilers (FBBs) differ from conventional boilers by emitting considerable amounts of nitrous oxide $\left(\mathrm{N}_{2} \mathrm{O}\right)$, owing to the low combustion temperature. $\mathrm{N}_{2} \mathrm{O}$ is a greenhouse gas and is also believed to contribute to the ozone depletion in the stratosphere. In order to benefit from the low emissions of $\mathrm{NO}_{\mathrm{x}}$ and $\mathrm{SO}_{2}$ from $\mathrm{FBBs}$, a solution is needed for the $\mathrm{N}_{2} \mathrm{O}$ emissions.

It is well known that the emissions of $\mathrm{NO}_{\mathrm{x}}, \mathrm{SO}_{2}$ and $\mathrm{N}_{2} \mathrm{O}$ can be significantly affected by changes in operational parameters like bed temperature and air supply. The problem is, that, while a measure taken to decrease one of the emissions may prove successful, it has the opposite effect on one or two of the others. The situation can be summarised as follows:

Raised bed temperature: $\mathrm{N}_{2} \mathrm{O}$ decreases, but $\mathrm{NO}$ increases and the sulphur capture efficiency is considerably reduced.

Lowered air-ratio: $\mathrm{N}_{2} \mathrm{O}$ and $\mathrm{NO}$ decreases, but the sulphur capture efficiency is considerably reduced.

Lowered fraction of primary air (increased degree of air staging): $\mathrm{NO}$ decreases and $\mathrm{N}_{2} \mathrm{O}$ decreases somewhat, but the sulphur capture efficiency is considerably reduced.

In conclusion, it is not possible to obtain a major reduction of the $\mathrm{N}_{2} \mathrm{O}$ emission from changes in parameters of operation, because of the negative effects on other emissions.

However, this coupling of positive effects on $\mathrm{N}_{2} \mathrm{O}$ to negative effects on other pollutants can be circumvented by addressing the conditions in the upper and the lower parts of the combustion chamber separately. This is possible because of a difference between the emissions with regard to the conditions in 
the upper and lower part: The conditions in the upper part are important for the $\mathrm{N}_{2} \mathrm{O}$ emission, while the effect of the conditions in the lower part is small. The NO emission and the sulphur capture, on the other hand, are affected by the conditions both in the lower and in the upper part of the combustion chamber.

The present paper reviews two methods of $\mathrm{N}_{2} \mathrm{O}$ reduction which selectively influence the conditions in the upper and lower part, one method which uses temperature as parameter and one which uses air supply:

1. Afterburning. This method involves extra fuel addition in the upper part of the combustion chamber (i.e. in the cyclone inlet) thereby increasing the temperature in the cyclone while the bed temperature can be maintained unchanged. Thereby a significant decrease in $\mathrm{N}_{2} \mathrm{O}$ can be obtained without affecting the conditions for low $\mathrm{NO}$ and $\mathrm{SO}_{2}$ emissions.

2. Reversed air staging. This method involves a reversal of the conditions normally used, supplying more oxygen to the bottom part and less to the upper part. Such a reversal of the conditions compared to normal air staging can be accomplished as follows: The combustor air-ratio is kept close to unity. No secondary air is used in the combustion chamber and all air is added in the bottom zone, except for some air which is supplied for final combustion downstream the cyclone, giving a total air-ratio of 1.2. The increased air-ratio of the bottom part makes this part more oxidising compared to normal air staging. The gradual consumption of oxygen with height, decreases the average oxygen concentration from the bottom and upwards, approaching very low oxygen concentrations in the top zone of the combustion chamber and the cyclone, since the combustor air-ratio is kept at about unity.

\section{EXPERIMENTAL CONDITIONS}

The $12 \mathrm{MW}$ circulating FBB used for the experiments has the features of a commercial boiler, but was built for the purpose of research. The boiler is shown in Fig. 1. The height of the combustion chamber is $13.5 \mathrm{~m}$ and the square cross-section is about $2.5 \mathrm{~m}^{2}$. The fuel used was bituminous coal. Further details on the boiler, the operating conditions, the properties of fuel and limestone and the system for data collection including gas analysis, are given in [1-5].

Afterburning. During the afterburning tests, the temperature in the cyclone and in the uncooled exit duct after the cyclone outlet was increased by fuel injection in three positions in the cyclone inlet (FI in Fig. 1). In some cases additional air was supplied in the cyclone outlet ( $\mathrm{r} 5$ ). Five injection fuels were tested - liquid petroleum gas (LPG), fuel oil, pulverized wood, sawdust and pulverized coal - although the data presented below are for gas if not otherwise indicated.

Reversed air staging: The air supplied to the bottom bed corresponds to an air-ratio of about 1 , i.e. stoichiometric conditions. Since no secondary air is added in the combustion chamber, this airratio (the combustor air-ratio) is maintained in the entire combustion chamber and the cyclone. Additional air is supplied in the cyclone outlet (r5) giving a total air-ratio of 1.2. The reversed air staging is compared to normal air staging with $60 \%$ primary air supplied to the bottom bed and $40 \%$ secondary air supplied at $2.2 \mathrm{~m}$ height ( $\mathrm{r} 2)$, i.e. with an air-ratio of about 0.7 in the bottom part and 1.2 above the secondary air supply.

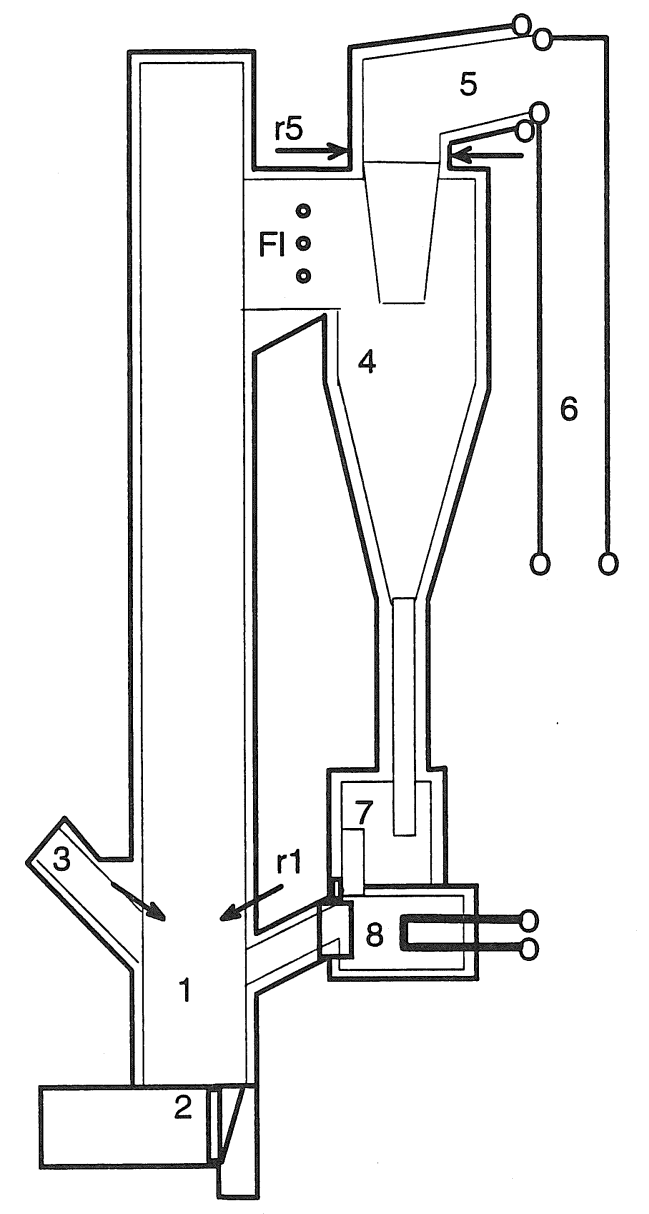

Fig. 1. Chalmers $12 \mathrm{MW}$ boiler. 1. combustion chamber; 2. air plenum; 3. fuel feed chute; 4. cyclone; 5. exit duct; 6. convection cooling section; 7. particle seal; 8. particle cooler; $\rightarrow \mathrm{r} 1$ and $\mathrm{r} 5$ secondary air nozzle inlets; - FI fuel injection inlets. 


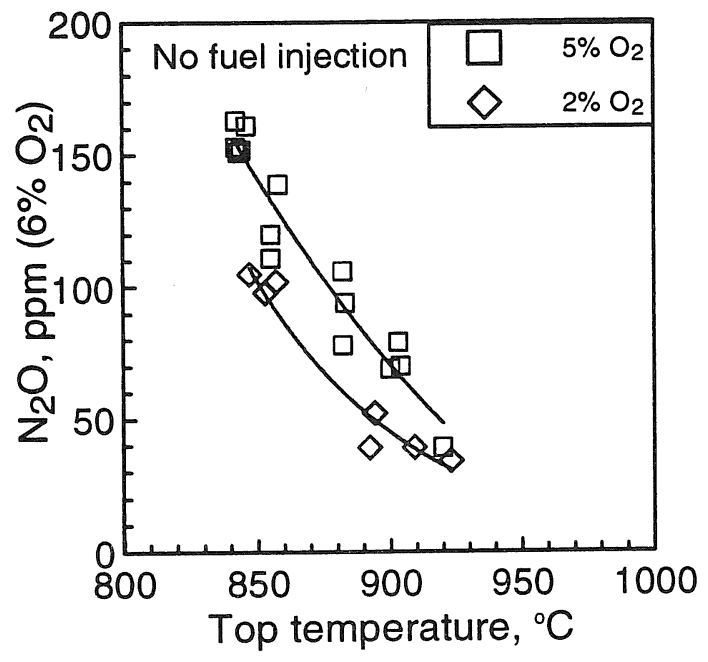

Fig. 2. $\mathrm{N}_{2} \mathrm{O}$ emission without afterburning vs. combustion chamber temperature.

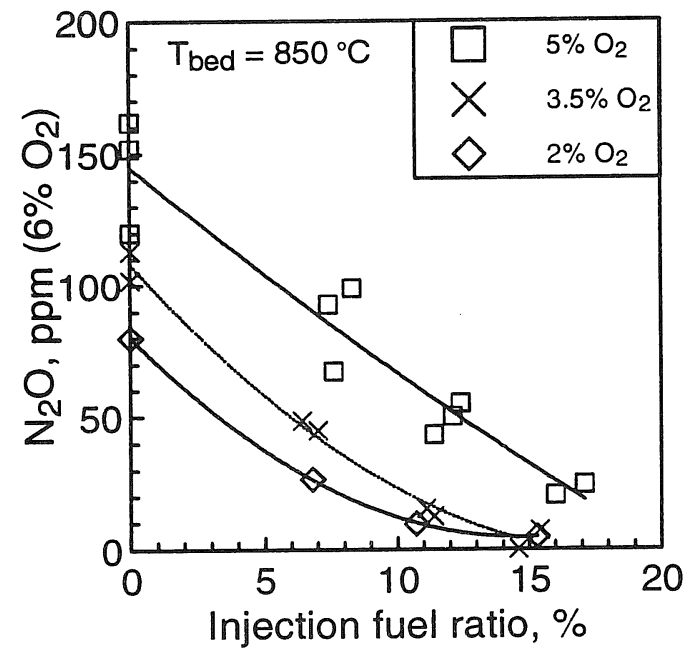

Fig. 4. $\mathrm{N}_{2} \mathrm{O}$ emission vs. injection fuel ratio.

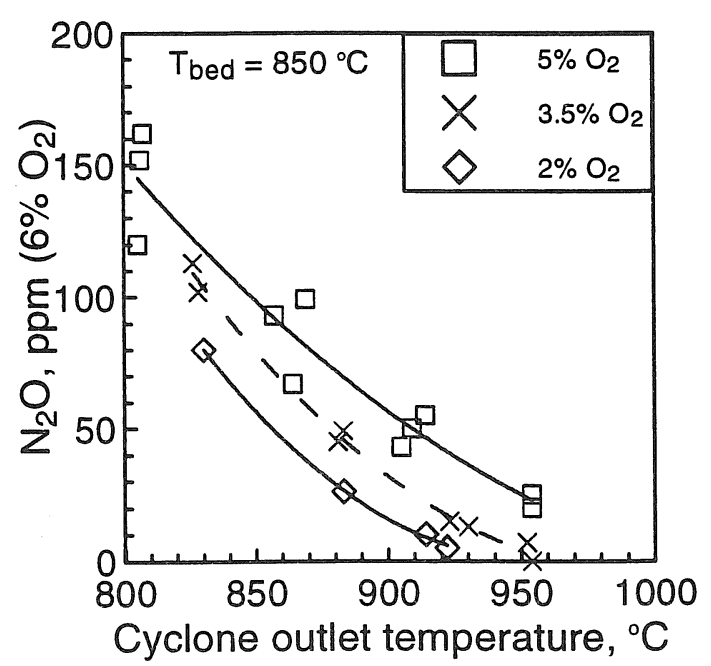

Fig. 3. $\mathrm{N}_{2} \mathrm{O}$ emission vs. cyclone outlet temperature. Excess air-ratios (expressed as $\mathrm{O}_{2}$ ) refer to values before fuel addition.

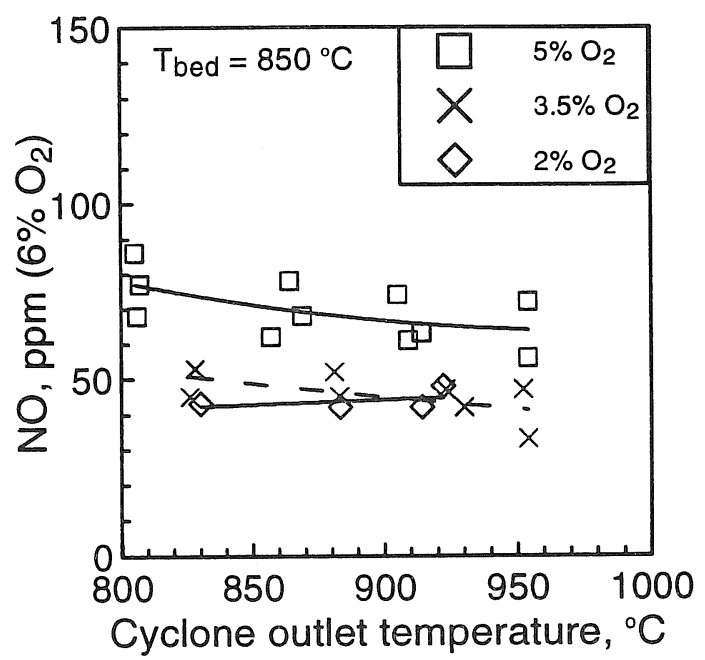

Fig. 5. NO emission vs. cyclone outlet temperature.

\section{AFTERBURNING}

The effect of air-ratio and temperature on $\mathrm{N}_{2} \mathrm{O}$ without fuel injection is illustrated by Fig. 2. Here the temperature and the air-ratio have been changed in the entire combustion chamber, which causes a significant decrease of the $\mathrm{N}_{2} \mathrm{O}$ emission, but also high emissions of $\mathrm{NO}$ and a very inefficient sulphur capture. With fuel injection in the cyclone inlet the temperature in the cyclone can be increased, while a constant bottom bed temperature is maintained. Thus, a similar decrease in $\mathrm{N}_{2} \mathrm{O}$, as in Fig. 2, is obtained without affecting the conditions in the combustion chamber, Fig. 3. The lines showing decreasing $\mathrm{N}_{2} \mathrm{O}$ concentration as a consequence of an increasing temperature are the effect of a gradually increased rate of fuel injection. This is seen in Fig. 4 where the same data are shown versus the injection fuel ratio, i.e. energy in afterburning fuel divided by energy in primary fuel.

As seen in Fig. 5 there is no negative effect of fuel injection on the NO emission, instead the NO decreases slightly with increased temperature. Even though the temperature effect is restricted to the cyclone, a negative effect on NO would be expected; the reason why this is not the case is probably the 


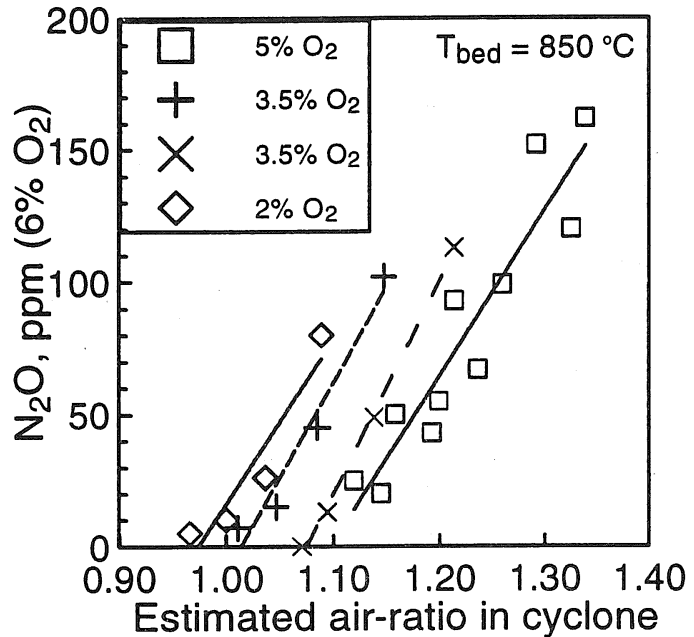

Fig. 6. $\mathrm{N}_{2} \mathrm{O}$ emission vs. air-ratio in cyclone. $\diamond,+$ air addition in cyclone outlet.

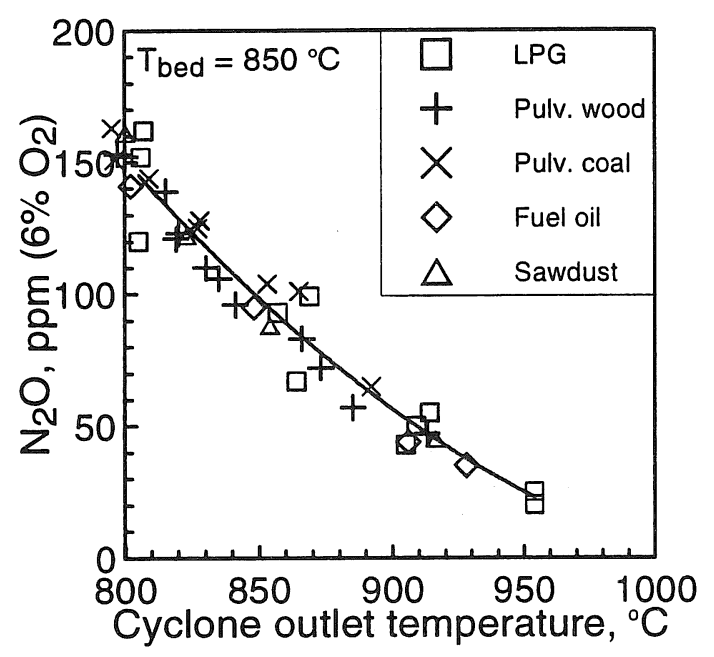

Fig. 8. $\mathrm{N}_{2} \mathrm{O}$ emission vs. cyclone outlet temperature. Comparison between different afterburning fuels.

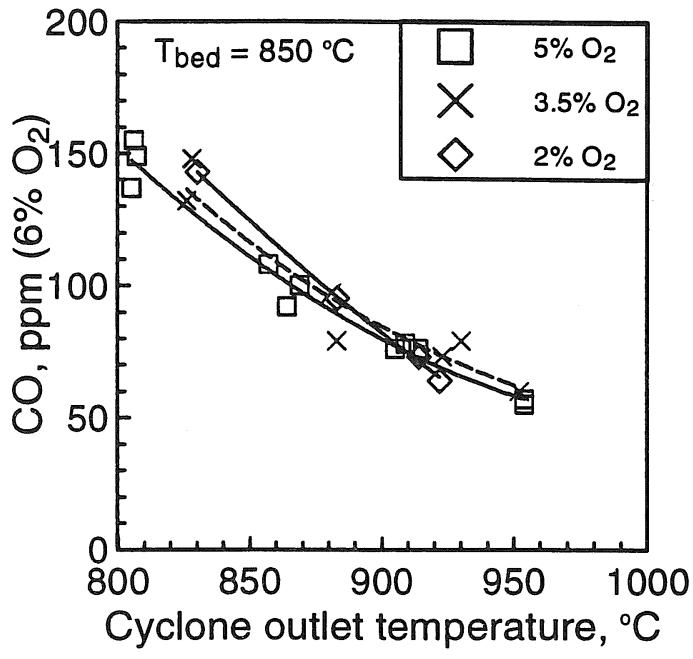

Fig. 7. $\mathrm{CO}$ emission vs. cyclone outlet temperature.

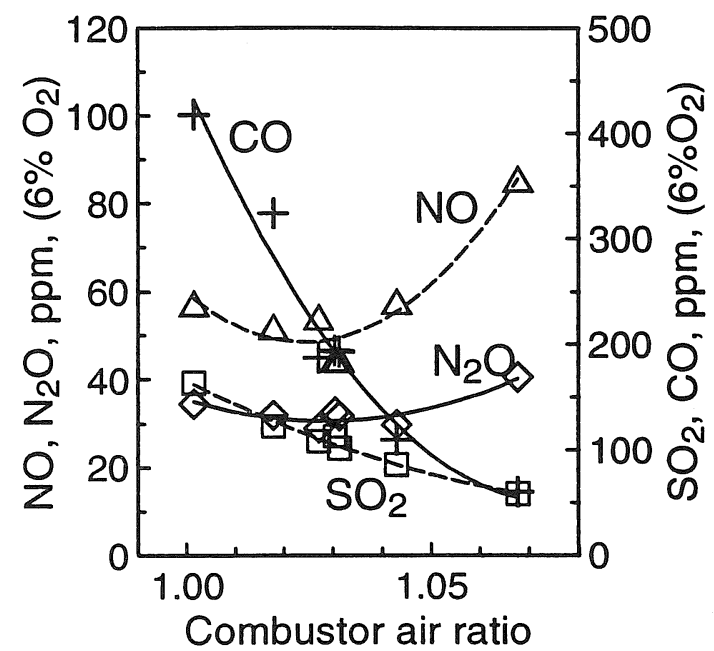

Fig. 9 Emissions vs. combustor air-ratio under reversed air staging.

simultaneous decrease of air-ratio in the cyclone, Fig. 6. The increased temperature in the cyclone also contributes to a decreased $\mathrm{CO}$ emission, Fig. 7.

Most of the experiments with afterburning were made on a sand bed, i.e. with no limestone addition. The test series performed with limestone addition showed no effect on the sulphur capture efficiency, [1]. These tests were only made for the higher air-ratio, i.e. for an initial oxygen flue gas concentration of $5 \%$. $\mathrm{N}_{2} \mathrm{O}$.

A comparison to other injection fuels, Fig. 8, shows that all the fuels tested cause a similar reduction in

\section{REVERSED AIR STAGING}

With a bituminous coal of normal sulphur content, reversed air staging, if compared to normal air staging, has been shown to reduce the $\mathrm{N}_{2} \mathrm{O}$ emission to one fourth $(25 \mathrm{ppm})$ and $\mathrm{NO}$ to half $(40 \mathrm{ppm})$ with a maintained sulphur capture efficiency of $90 \%$, although the $\mathrm{CO}$ emission increases, [3-5]. This result is one example of what can be obtained with reversed air staging. For an optimization of the emissions three parameters are available:

i) combustor air-ratio: an increase gives lower $\mathrm{CO}$ and $\mathrm{SO}_{2}$ and higher $\mathrm{NO}$ and $\mathrm{N}_{2} \mathrm{O}$, 


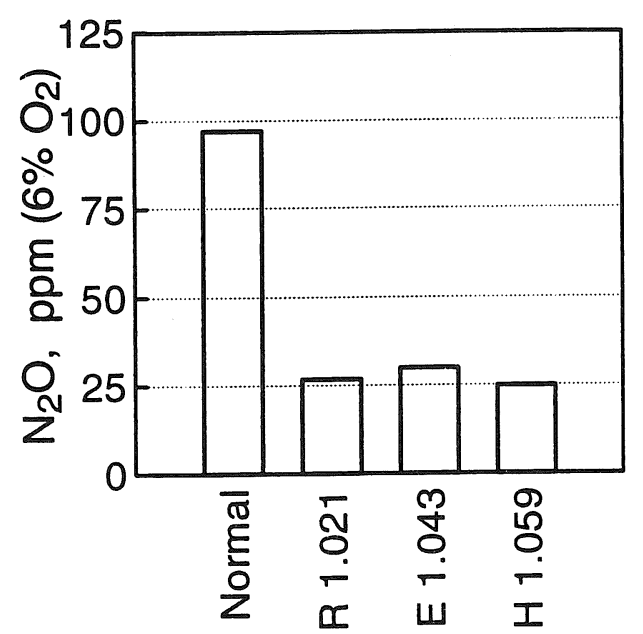

Fig. 10. Emission of $\mathrm{N}_{2} \mathrm{O}$ for three cases of reversed air staging compared to normal air staging.

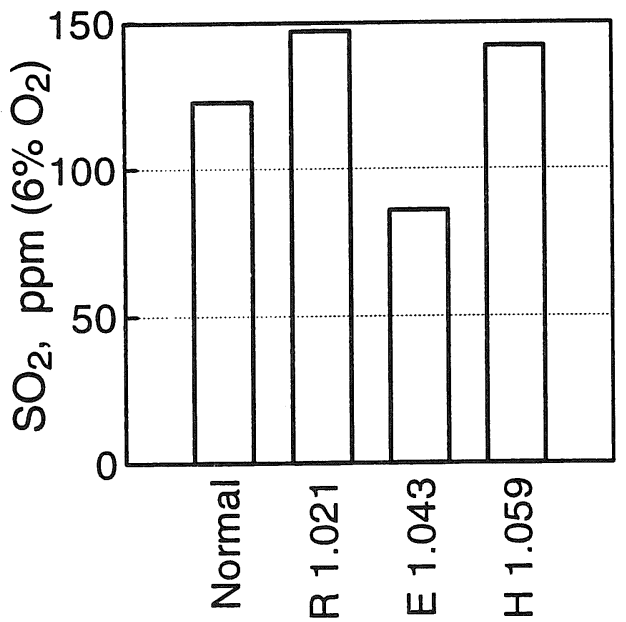

Fig. 12. Emission of $\mathrm{SO}_{2}$ for three cases of reversed air staging compared to normal air staging.

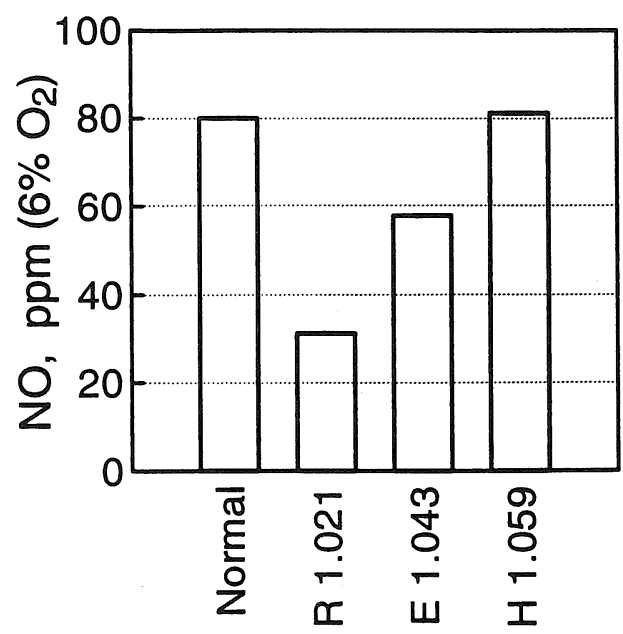

Fig. 11. Emission of NO for three cases of reversed air staging compared to normal air staging.

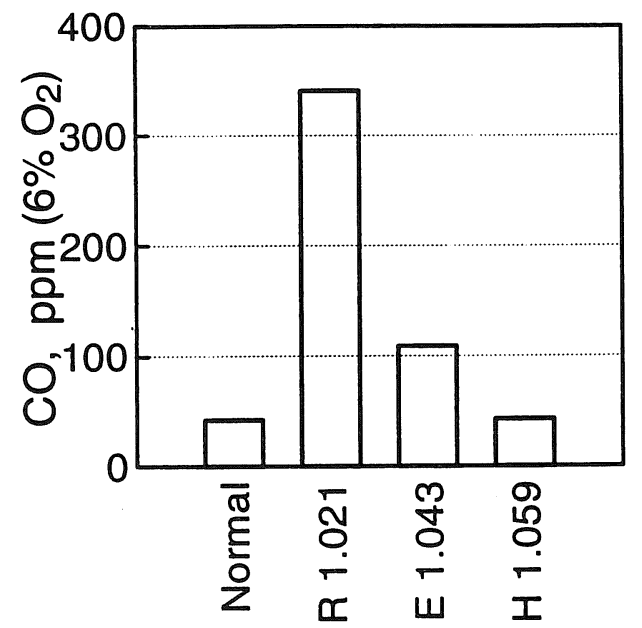

Fig. 13 Emission of $\mathrm{CO}$ for three cases of reversed air staging compared to normal air staging.

ii) temperature: an increase results in lower $\mathrm{CO}$ and $\mathrm{N}_{2} \mathrm{O}$ and higher $\mathrm{NO}$ and $\mathrm{SO}_{2}$,

iii) limestone addition: an increase gives lower $\mathrm{SO}_{2}$, somewhat lower $\mathrm{CO}$ and $\mathrm{N}_{2} \mathrm{O}$ and higher $\mathrm{NO}$. Increases in the first two parameters can also be expected to in rease the combustion efficiency which needs to be considered in an optimization. The effect of the first parameter, combustor air-ratio, is illustrated by Fig. 9.

Figures 10-13 show the emissions during normal air staging compared to reversed air staging. The reversed air staging cases are carried out with normal limestone addition ( $R$ ), extra limestone addition at a somewhat higher combustor air-ratio $(\mathrm{E})$, and higher bed temperature in combination with extra limestone and a high combustor air-ratio $(\mathrm{H})$. The combustor air-ratios are indicated by the numbers in the $\mathrm{x}$-axis labels. The three cases of reversed air staging in the figures were chosen to have approximately constant $\mathrm{N}_{2} \mathrm{O}$ and $\mathrm{SO}_{2}$ emissions. The cases show that the $\mathrm{CO}$ emission can be reduced from more than $300 \mathrm{ppm}$ to the level achieved with normal air staging, below $50 \mathrm{ppm}$. The penalty of the decreased $\mathrm{CO}$ emission, however, is that the halving of $\mathrm{NO}$ is lost.

In conclusion, it is possible to reduce $\mathrm{N}_{2} \mathrm{O}$ to one fourth with the emissions of $\mathrm{NO}, \mathrm{SO}_{2}$ and $\mathrm{CO}$ being unaffected. If a rise in $\mathrm{CO}$ is accepted, an additional reduction of the $\mathrm{NO}$ emission can be obtained. A further reduction of the emissions can be obtained by lowering the load, [5]. 


\section{DISCUSSION AND CONCLUSIONS}

Two methods for decreasing the $\mathrm{N}_{2} \mathrm{O}$ emission have been presented. Both methods are based on the same principle, i.e. that the $\mathrm{N}_{2} \mathrm{O}$ emission, as opposed to the emissions of $\mathrm{NO}$ and $\mathrm{SO}_{2}$, is only affected by the conditions in the cyclone and the upper part of the combustion chamber. The insensitivity of $\mathrm{N}_{2} \mathrm{O}$ to the conditions in the lower part is explained by the destruction of $\mathrm{N}_{2} \mathrm{O}$ in the combustion chamber. The destruction has been verified by addition of $\mathrm{N}_{2} \mathrm{O}$ to the bottom part of the Chalmers FBB; only a very small part of the added $\mathrm{N}_{2} \mathrm{O}$ remained in the flue gas, [6]. Despite the destruction, gas measurements inside the combustion chamber show a marked $\mathrm{N}_{2} \mathrm{O}$ increase with height owing to simultaneous formation, [7].

The two methods investigated both adapt the conditions in the upper part and/or the cyclone to $\mathrm{N}_{2} \mathrm{O}$ reduction, while providing conditions in the lower part of the combustion chamber suitable for sulphur capture and low NO emissions.

Afterburning decreases the $\mathrm{N}_{2} \mathrm{O}$ emission with up to about $90 \%$, without significant effects on other emissions, except a decrease in CO. The drawback of the method are the extra costs involved in fuel injection, e.g. a more expensive fuel and arrangements for efficient afterburner construction.

Reversed air staging is able to reduce the $\mathrm{N}_{2} \mathrm{O}$ emission to one fourth, without significant effects on the other emissions. A minor drawback of reversed air staging is a somewhat higher power consumption for the supply of air to the bottom part.

The combustion efficiency is important and, in the first available measurements, this was seen to be lower for reversed air staging. These results, however, were obtained for high CO emissions, 300-400 ppm, [3]. Recent investigations indicate that the combustion efficiency is correlated to the CO emission, and no significant difference in combustion efficiency between normal and reversed air staging was seen for lower CO emissions, i.e. 100-200 ppm CO. Considering the means available to reduce the CO emission, it should thus be possible to realize a good combustion efficiency.

The two methods have been tested in a boiler under a number of different conditions. Although the methods have been proved in this scale, further work would of course be needed to find the best design and operating conditions for a commercial application.

The present experience demonstrates the applicability of the methods. A comparison between the methods has to await a commercial implementation but afterburning can be expected to involve higher costs, while on the other hand a higher reduction of $\mathrm{N}_{2} \mathrm{O}$ is possible. The two methods should also be possible to combine, which, hopefully, could result in even lower emissions.

\section{ACKNOWLEDGEMENTS}

This work has received financial support from the Swedish National Board for Industrial and Technical Development (NUTEK), the Swedish Energy Development Corporation (SEU), the Nordic Gas Technology Centre (NGC), Kvaerner Enviropower AB and the Swedish National Testing and Research Institute.

\section{REFERENCES}

1. L. Gustavsson and B. Leckner, Ind. Eng. Chem. Res. 34, 1419 (1995).

2. L. Gustavsson Reduction of the $\mathrm{N}_{2} \mathrm{O}$ Emissions from Circulating Fluidized Bed Combustion by Afterburning, PhD Thesis, Chalmers University of Technology, Göteborg, Sweden, 1995.

3. A. Lyngfelt, L.-E. Åmand and B. Leckner, Proc. Int. Conf. Fluid. Bed Combustion 13, 1049 (1995)

4. A. Lyngfelt, L.-E. Åmand and B. Leckner, Energy Fuels 9, 386 (1995).

5. A. Lyngfelt, L.-E Åmand, M. Karlsson and B. Leckner, "Reduction of $\mathrm{N}_{2} \mathrm{O}$ emissions from fluidised bed combustion by Reversed air staging," "Combustion \& Emissions Control," London, 3-5 Dec. 1995. 6. L.-E. Åmand and B. Leckner, Energy Fuels 7, 1097 (1993).

7. L.-E. Åmand and B. Leckner, Fuel 73, 1389 (1994). 